\title{
Community Involvement to Address a Long-standing Invasive Species Problem: Aspects of Civic Ecology in Practice $\odot$ a $₫$
}

\author{
Rebecca W. Dolan, Kelly A. Harris and Mark Adler
}

\begin{abstract}
Invasive non-native species (INS) are found in every city around the globe, but their impacts in urban settings as biological agents of visual pollution that block views of natural landscapes and disconnect citizens from nature are not as often addressed as comprehensively as their impacts in natural areas or agricultural settings. The multiple impacts of INS in cities make them ideal candidates for aspects of Civic Ecology Practice, where local environmental stewardship action is taken to enhance green infrastructure and community well-being in urban and other human-dominated systems. We present details of a community driven program focused on removal of an INS, Amur bush honeysuckle (Lonicera maackii), from banks of a creek in Indianapolis, Indiana, in the midwestern USA. Unlike many civic ecology practices, this project was motivated by community response to the long-developing environmental, social, and economic impacts of an INS and includes involvement of a major corporation. In response to local residents' concerns and following months of planning, over 2,000 volunteers removed more than $760 \mathrm{~m}^{3}$ of Amur bush honeysuckle from 30 acres of land along Fall Creek during a single day. The honeysuckle removal served ecological and environmental goals of removing an invasive species, but it also helped foster in citizens a sense of place and connection with Indianapolis' waterways, reflecting local history and culture. Aspects of the project can serve as a model for action in other cities.
\end{abstract}

Keywords: Indianapolis, invasive non-native species, Lonicera maackii, urban ecology

\section{\$) Restoration Recap (\%}

- Civic Ecology Practices are local environmental stewardship actions undertaken in human-dominated landscapes with the goal of enhancing green infrastructure and community well-being. Civic Ecology emphasizes the role of residents within the system as agents of change.

- Invasive non-native species degrade green infrastructure and erode community well-being. We report on a Civic Ecology Practice organized by a Collective Impact Model partnership involving individuals, neighborhood groups, non-profits, city government, universities, consultants and, notably, a major private sector corporation. As a

Color version of this article is available through online subscription at: http://er.uwpress.org

2. This open access article is distributed under the terms of the CC-BYNC-ND license (http://creativecommons.org/licenses/by-nc-nd/3.0) and is freely available online at http://er.uwpress.org

Supplementary materials are freely available online at: http://uwpress.wisc.edu/journals/journals/er-supplementary.html

Ecological Restoration Vol. 33, No. 3, 2015

ISSN 1522-4740 E-ISSN 1543-4079

○2015 by the Board of Regents of the University of Wisconsin System. result, 2,000 volunteers removed more than $760 \mathrm{~m}^{3}$ of invasive Amur bush honeysuckle from 30 acres during a single day.

- We discuss logistics and timetable considerations for undertaking such a large-scale project and outline best management practices for bush honeysuckle removal in the Midwestern US.

- Lessons learned include the importance of recognizing the impacts of invasive non-native plants on cultural, in addition to ecological, resources to broaden participation and community connection. 
Impacts of plant INS in natural areas and in agronomic settings have been recognized and quantified for some time. Fewer studies have addressed consequences of invasive species in cities, despite the fact that, as transit hubs and concentrations of high-density human population, urban areas are often points of introduction for invasives (Pyšek 1998). A recent International Union for Conservation of Nature (IUCN) report focusing on invasive species in European cities highlights ecological, economic, and social impacts (van Ham et al. 2013). Their findings include:

- Ecological effects-alteration of species composition resulting in loss of biodiversity and declines in primary productivity.

- Economic costs-diminished ecosystem services (e.g., erosion control), infrastructure deterioration, altered nutrient cycling, and declines in property value.

- Social impacts-perception of spaces overgrown with INS as signs of urban decay and loss of visual connection with natural features such as riparian corridors.

The report concludes that effective management of INS is often hindered by lack of manpower and technical expertise needed for successful removal. Hands-on experiences with INS control by a wide a range of citizens is recommended as more efficacious for increasing the general public's understanding of the issues relating to INS than newspaper articles and news stories.

When community members join together to address impacts of invasive species, it is a platform for aspects of civic ecology in action. Civic ecology practices are local environmental stewardship actions undertaken in human-dominated landscapes with the goal of enhancing green infrastructure and community well-being (Tidball and Krasny 2014). Civic ecology emphasizes the role of residents within the system as agents of change. Examples include tree plantings by local residents following Hurricane Katrina in New Orleans (Krasny and Tidball 2012) and community gardens planted on degraded vacant properties in Detroit (Krasny et al. 2014). Integral to civic ecology practice is the interdisciplinary interaction of individuals, communities, governmental institutions, and the ecosystems in which these practices take place (Krasny and Tidball 2012). This distinguishes civic ecology from other hands-on volunteer environmental or ecological activities such as citizen science initiatives, where traditionally, volunteers collect and process data as part of a research project initiated by a scientific investigator (Silverton 2009). Citizen science, or public participation in science, in this context is not community driven, but the definition has recently been expanded by some (e.g., Jordan et al. 2014, Silva and Kransy 2014) to also include collaborative and co-created projects in which public citizens also contribute to data analysis and interpretation and have expanded ownership over projects. Civic ecology practices are "selforganized" by community members (Tidball and Krasny 2007). Further, civic ecology practices are often sparked by environmental crises such as hurricanes or floods, but can also emerge after a period of sustained environmental and social deterioration (Kransy and Tidball 2015).

We present details of a long term civic ecology practice initiated by local residents and assisted by a wide range of partners from the wider community in Indianapolis, Indiana, a major city in the American Midwest. This project was motivated, not by a sudden environmental crisis, but by citizens' growing concern about the environmental, social, and economic impacts of an INS. Action was facilitated by a major corporation. Additional partners in this project, like many long-term civic ecology projects, include non-profit organizations, government agencies, universities, and the private sector. Goals of the paper are to present a model project whose motivation and logistics could be repeated in other communities and to highlight the impact of INS in urban areas where their major impact may not be primarily ecological, but social. INS in cities can be visual pollution, blocking citizens' views of urban nature and disconnecting them from the cultural heritage of historical landscapes. To our knowledge, ours is the first report in the literature of INS as a focus for civic ecology.

\section{Background}

Indianapolis is the 12th largest city in the United States. It has a population of ca. one million people, with an additional 500,000 in surrounding counties making up the metropolitan area. Population density in the city was ca. 2,230 people/mi. ${ }^{2}$ in 2010 (www.usa.com/indianapolisin-population-and-races.htm). Indianapolis was established as the capital of Indiana by an act of the United States Congress in 1819. The location was chosen, in part, because of its proximity to the White River and its tributaries which were considered important for commerce and transportation at the time.

One of the tributaries of the White River is Fall Creek, which flows through the Mid-North community of Indianapolis. Indianapolis recognized the potential and beauty of Fall Creek as early as 1894 when there was a call for a plan to create a linear park and new street to parallel Fall Creek. In 1909 George Edward Kessler, a St. Louis, Missouri landscape architect and urban planner, developed a grand parks and boulevard plan for Indianapolis' four major waterways. The parks and boulevard system was meant to take advantage of "picturesque, meandering streams, broad vistas, and fine stand of timber. It was also practical, since it protected waterways from pollution and acted as a flood control device" (Diebold 1994). Kessler's Plan fostered residential growth in sparsely populated areas and reinforced the tendency of citizens to regard the north and east sides of the city as desirable neighborhoods (Diebold 1994). 


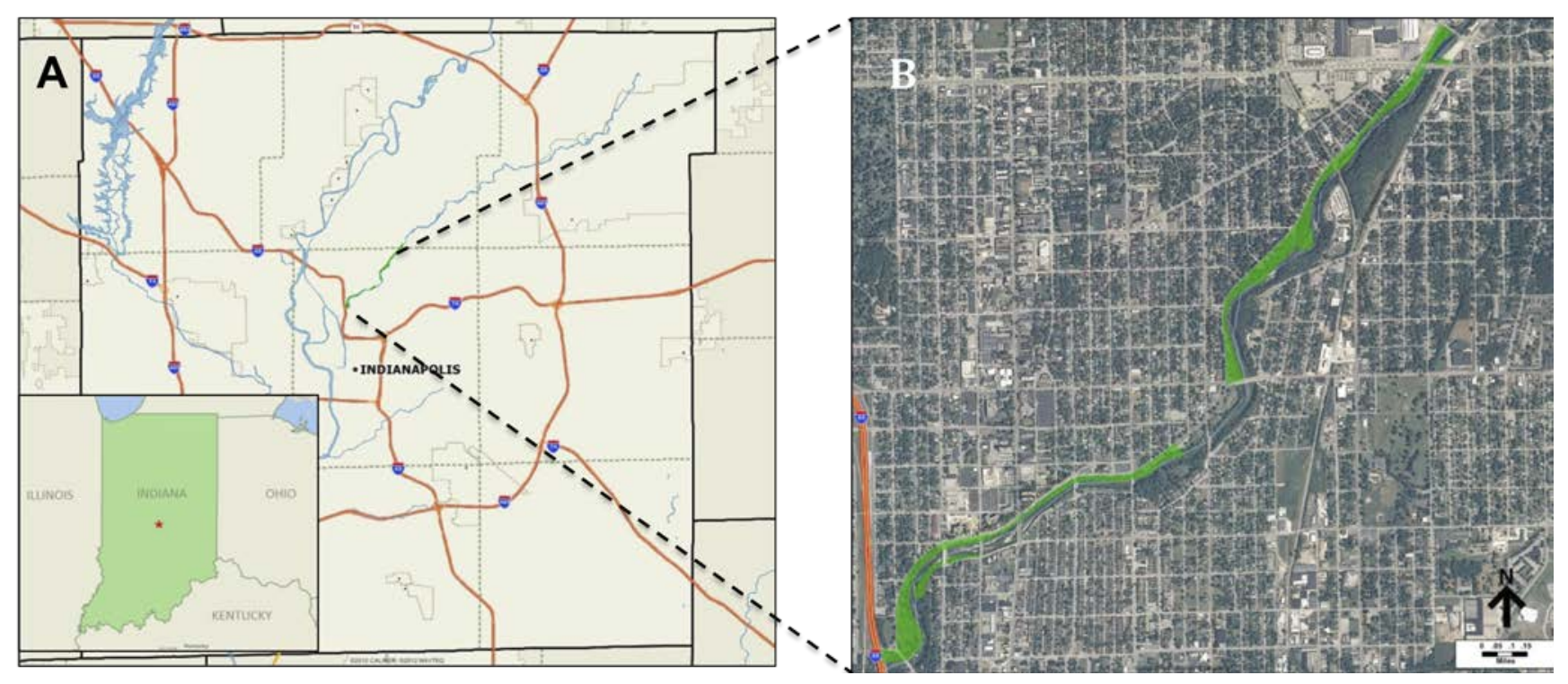

Figure 1. Location of Indianapolis in the United States and the location of FC-HRP activities along Fall Creek.

Kessler's Plan was based on a three-part hierarchy of park needs: smaller parks and squares, larger parks, and the boulevards connecting them and providing continuity to the whole system. The smaller parks and squares along the waterways were to be utilized as neighborhood parks within walking distance of one's home. The larger parks were to provide the public with open space for active sports, family outings, and community events. The boulevards were to connect the parks and provide a backbone for city development (Maloney and Remenschneider 1983). The parkway and boulevard system still functions today as roadways, but much of the larger vision of the Kessler Plan has been lost.

\section{Community Call to Action}

Recognizing the value of neighborhood plans as catalysts for urban renewal, 492 neighborhood stakeholders and 79 organizations under the guidance of Indiana's Local Initiative Support Corporation, came together to develop the Mid-North Quality of Life Plan (QLP). The plan, developed and implemented by residents, institutions, schools, businesses, places of worship, associations, and organizations, was a framework for improvement, building on existing community assets and emphasizing significant community engagement (www.midnorthplan.org). From the Mid-North Quality of Life Plan (QLP), an overall goal was identified to make Fall Creek a destination for the community. This led to creation of the Destination Fall Creek taskforce, made up of residents from the six neighborhoods surrounding Fall Creek. An involved resident recalls, "we were coming to the conclusion that until folks could see the Creek, it would be hard to get much enthusiasm for Destination Fall Creek. On a cold rainy ugly day in 2011, we worked to clear a sight line to the Bridge and the Creek from the Parkway. 40 people or so. This day had a huge impact on me. I saw how much effort was involved (huge) and then noticed how quickly the invasives grew back... . denser than ever. Simply whacking them.... had the opposite effect from the desired."

The focus of Destination Fall Creek is to capitalize on the historic Fall Creek corridor (Figure 1) north of the city to weave together diverse neighborhoods, encourage civic, ecological, and entrepreneurial ethics, and to help reestablish the Mid-North area "on the regional map as a unique and progressive place to call home" (dfcindy.org). This goal recognized that the Kessler Plan landscaping that was once carefully designed had been displaced by invasive Amur bush honeysuckle (Lonicera maackii) that blocked off most views of the creek, a case of INS as visual and biological pollution. The Mid-North QLP proposed that stream banks be restored through neighborhood cleanups, invasive honeysuckle removal, and the reintroduction of native landscaping that would restore beautiful vistas of the creek from adjacent streets, homes, and parks. Local residents, however, did not have the resources, knowledge, or ability to tackle the problem. Further, there was resistance in city government to allowing volunteers to remove honeysuckle on city property.

Citywide in recent history, Indianapolis has turned its back on the many waterways that flow through it. A major step toward change came in October, 2010 from the CEO's For Cities Livability Challenge (www.ceosforcities.org/ events/us-livability-challenge/). Over 75 urban leaders came to Indianapolis for the Livability Challenge in order to determine how to make art, nature, and beauty accessible every day by everyone living in cities, using Indianapolis as an example. They created 10 key areas of improvement for cities, with one being "Reconnect to the River" which outlined the idea of reclaiming riverfronts to create new economic value that promotes social and environmental 
welfare. Throughout 2011, these 10 ideas were promoted to key Indianapolis leaders and stakeholders.

While the Mid-North Quality of Life Plan was being developed, a major employer headquartered in Indianapolis, the Fortune 500 Company Eli Lilly and Company, was holding annual Lilly Global Day of Service (LDOS) projects. These outreach initiatives involve a day of service during the work week in communities with Lilly facilities where employees help civic, community and non-profit organizations achieve their goals. The LDOS is one of the largest single day volunteer programs in the world (www.lilly.com/Responsibility/communities/Pages/ global-day-of-service).

In 2011, Eli Lilly and Company decided they wanted to advance their 2012 annual Lilly Global Day of Service in Indianapolis to increase external organization involvement and to identify sustainable projects that would make Indianapolis a better place to live, work, and play. The Livability Challenge was brought to Lilly's attention and upon review of the report they found the avenue through which they could accomplish their goals, working together to turn Indianapolis' waterways into community assets using science and public service. Staff at Lilly vetted the idea thoroughly and brought in leaders from the public, private, and nonprofit sectors to form a steering committee, and thus Reconnecting to Our Waterways (ROW) was created.

The ROW initiative was designed using the "collective impact" principle that more can be achieved through collaboration of many than through the work of one (Supplementary Materials) (Kania and Kramer 2011). Within a few months, ROW had over 150 partner organizations (for a current list of partner organizations visit reconnectingtoourwaterways.org/who/partners/) and had established a common vision and goal, organized around elements with guiding principles (Table 1), and six initial focus areas. ROW continued to define their principles and explore ideas through public brainstorming events and through convening experts into Element Committees, which lead to the creation of metrics (Table 1) and the identification of potential ROW destination locations. ROW continues to evolve and adapt to the ever-changing needs and desires of Indianapolis communities. The Mid North Quality of Life Plan, with its focus on Fall Creek, aligned with the mission of ROW and the neighborhood became a partner, recognizing the resources that Eli Lilly \& Company would provide to help citizens achieve their local vision.

\section{Target Invasive Non-native Species- Amur Bush Honeysuckle}

In North America, Asian bush honeysuckles are a suite of invasive shrubs in the genus Lonicera. In the Midwest, the most prominent species is Lonicera maackii, Amur bush honeysuckle. It is a multi-stemmed shrub that can grow 20 feet tall (Luken and Thieret 1996) and often forms dense thickets. Its preferred habitat is forest edges; it rarely grows in open, unshaded habitats (Luken and Thieret 1996). Its phenology attests to its non-native origins; Amur bush honeysuckle leafs out several weeks earlier than native shrubs and retains its leaves much longer in the fall (Luken and Thieret 1996). Seeds are dispersed in red berries that are eaten by birds (Ingold and Craycraft 1983).

Amur bush honeysuckle was promoted by the USDA Soil Conservation Service (now the Natural Resource Conservation Service) as a suitable ornamental plant for soil stabilization and wildlife habitat improvement. The agency selected cultivars for greater fruit production and made seed available to commercial nurseries for sales to private landowners from the 1960s until 1984 (Luken and Thieret 1996). It is now recognized that Amur bush honeysuckle berries are not a quality food source for birds, especially Neotropical migrants (Ingold and Craycraft 1983) and that the architecture of the branches makes nests placed in the shrubs more easily predated than nests located in native shrubs (Schmidt and Whelan 1999). Amur bush honeysuckle is not currently considered especially effective at stabilizing soil (Luken and Thieret 1996) and its leaf phenology and allelopathy have been documented to inhibit growth of native herbaceous and woody species (Gould and Gorchov 2000, Collier et al. 2002, Hartman and McCarthy 2007).

Honeysuckle was an ideal target because it impacts all elements identified by ROW as priority action items, supporting the holistic approach embraced by the initiative (Table 1). At the same time, it was appreciated that removal of Amur bush honeysuckle would provide benefits beyond addressing the above concerns, including educational opportunities for the wider community to learning what INS are and appreciate their impacts. Surveys of the banks of Fall Creek in summer 2012 prior to the LDOS documented a density of ca. 2,000 stems per acre, generally considered a very heavy infestation (Rebecca Dolan, Butler University, pers. observation).

\section{Logistics}

Invasive removals had been done in the past as part of the LDOS, but in scattered places throughout Indianapolis. While these activities had immediate impact, in many cases long-term care to ensure the invasive material would not come back was not completed. For work initiated under ROW, the goal was to not only have immediate impact, but to thoughtfully revisit these spaces applying best practices while using resources at hand in unique ways. Keep Indianapolis Beautiful, Inc. (KIB), a civic nonprofit with the mission to engage diverse communities to create vibrant public places, helping people and nature thrive (www.kibi.org), took the lead in coordinating the LDOS work focused on removal of Amur bush honeysuckle along Fall Creek, hereafter referred to as the Fall 
Table 1. Organizational and conceptual structure for Reconnecting to Our Waterways (ROW) Civic Ecology group formed in Indianapolis, Indiana, USA. The Ecology Element, Metrics and Outcome are most germaine to this paper. Other Elements' Metrics and Outcomes were fostered as well and documenting data are still being collected. How presence of Amur honeysuckle impacts each of the Elements is listed.

\begin{tabular}{|c|c|c|c|c|}
\hline Element & Principle & \# & Metric & Honeysuckle Impact \\
\hline Aesthetics & $\begin{array}{l}\text { The natural beauty of the } \\
\text { waterways and surround- } \\
\text { ing neighborhoods is } \\
\text { revealed and encouraged } \\
\text { to flourish; artists gener- } \\
\text { ate public conversations } \\
\text { that are rooted in these } \\
\text { environments }\end{array}$ & 2 & $\begin{array}{l}\text { Incorporate new and enhance } \\
\text { existing aesthetic elements, } \\
\text { experiences and/or areas of natural } \\
\text { beauty within } 1 / 2 \text { mile of waterway } \\
\text { Improve artists' relationships with } \\
\text { communities located within } 1 / 2 \\
\text { mile of waterways }\end{array}$ & $\begin{array}{l}\text { Decreased natural beauty because of } \\
\text { monoculture and blocking natural } \\
\text { view to waterway, view-shed (opin- } \\
\text { ion based- some people liked how } \\
\text { honeysuckle looked and were upset } \\
\text { by it being removed) }\end{array}$ \\
\hline Connectivity & $\begin{array}{l}\text { Through bike trails or a } \\
10 \text {-minute walk, connect } \\
\text { the neighborhoods sur- } \\
\text { rounding our waterways } \\
\text { to art, nature, and beauty }\end{array}$ & 3 & $\begin{array}{l}\text { Create a connectivity system } \\
\text { between ROW focus neighbor- } \\
\text { hoods and their destination } \\
\text { locations and waterways }\end{array}$ & $\begin{array}{l}\text { Physically blocked people's ability } \\
\text { to see and access the waterway and } \\
\text { therefore the connection of the Fall } \\
\text { Creek neighborhood to the waterway } \\
\text { system of the city }\end{array}$ \\
\hline Ecology & $\begin{array}{l}\text { Establish and enhance } \\
\text { robust ecosystems along } \\
\text { the waterways and con- } \\
\text { nected neighborhoods } \\
\text { with the ultimate goal of } \\
\text { improving the physical, } \\
\text { chemical and biological } \\
\text { measures of water quality }\end{array}$ & 4 & $\begin{array}{l}\text { Improve overall stream health } \\
\text { Promote natural and physical } \\
\text { infrastructure to improve the } \\
\text { ecosystem }\end{array}$ & $\begin{array}{l}\text { Impacted ecological form and func- } \\
\text { tion by reducing understory diversity, } \\
\text { out-competing native herbaceous } \\
\text { plants, shrubs seedlings and tree } \\
\text { saplings, while reducing overstory } \\
\text { productivity }\end{array}$ \\
\hline Economics & $\begin{array}{l}\text { Recognize and leverage } \\
\text { strengths within each tar- } \\
\text { geted area, and collabo- } \\
\text { rate with all stakeholders } \\
\text { to create opportunities } \\
\text { for economic growth }\end{array}$ & 6 & $\begin{array}{l}\text { Increase capital investment within } \\
1 / 2 \text { mile of waterways } \\
\text { Increase brownfield parcels } \\
\text { remediation within } 1 / 2 \text { mile of } \\
\text { waterway }\end{array}$ & $\begin{array}{l}\text { Negatively affected property values } \\
\text { and economic investment; properties } \\
\text { near Fall Creek were not benefiting } \\
\text { from their location near this potential } \\
\text { asset }\end{array}$ \\
\hline Education & $\begin{array}{l}\text { Actively engage people } \\
\text { of all ages, cultures, } \\
\text { and affluence in learn- } \\
\text { ing environments that } \\
\text { pose essential scientific } \\
\text { questions of a healthy } \\
\text { Indianapolis watershed }\end{array}$ & 9 & $\begin{array}{l}\text { Incorporate educational elements } \\
\text { around the waterways and ROW } \\
\text { destination locations } \\
\text { Promote educational program- } \\
\text { ming, events, and campaigns } \\
\text { about the waterways in ROW } \\
\text { Focus Areas }\end{array}$ & $\begin{array}{l}\text { Local neighborhood citizens were } \\
\text { under-aware of the issues surround- } \\
\text { ing INS and did not know how the } \\
\text { control INS }\end{array}$ \\
\hline Well-being & $\begin{array}{l}\text { Create antidotes to } \\
\text { Nature Deficit Disorder } \\
\text { that nourish the spirit and } \\
\text { support good health and } \\
\text { fitness }\end{array}$ & 11 & $\begin{array}{l}\text { Promote waterways and destina- } \\
\text { tion locations as a resource for } \\
\text { improving health } \\
\text { Increase health and wellness pro- } \\
\text { graming along waterways }\end{array}$ & $\begin{array}{l}\text { Caused safety concern because of } \\
\text { overgrowth of shrubs that retain } \\
\text { their leaves through a long growing } \\
\text { season, providing potential cover for } \\
\text { miscreants }\end{array}$ \\
\hline Overall & & 12 & $\begin{array}{l}\text { Increase number of residents living } \\
\text { within } 1 / 2 \text { mile of waterways } \\
\text { Increase public awareness of } \\
\text { environmental importance, eco- } \\
\text { nomic impact and quality of life } \\
\text { contributions of the waterways }\end{array}$ & \\
\hline
\end{tabular}

Creek Honeysuckle Removal Project (FC-HRP; Figure 1). KIB was the most experienced non-profit in the city with directing large numbers of volunteers from business in hands-on environmental action, such as tree planting and maintenance. They worked with knowledgeable partners from the city and business community (especially staff from an environmental consulting company with experience in Amur bush honeysuckle removal and control) who helped guide the process and to successfully manage meaningful outcomes. 
Based on its experience with previous projects, staff at KIB recognized that there were major obstacles to be overcome in advance of the FC-HRP, including:

No best practices guidelines for Amur bush honeysuckle removal in Indianapolis. An early obstacle to be overcome was mixed opinions on best practices for Amur bush honeysuckle removal specific to riparian corridors in Indianapolis among city land management staff and KIB, fueling concerns that efforts would not be effective and that volunteers would not be adequately prepared to work on such a large scale project. To address this concern the ROW Ecology Committee convened a series of meetings for informed and interested parties (academics, agency personnel, consultants, and non-profit land managers) where best practices were developed and agreed to. A flow chart of the best practices guidelines developed is presented in Supplementary Figure S1.

Treatment in October, also the traditional month for LDOS, was deemed appropriate for removal of Amur bush honeysuckle by pulling small plants and lopping of branches of larger shrubs several inches above the ground. This work could be done by minimally trained volunteers. To kill the larger shrubs, cut stumps would be sprayed with herbicide by specially trained volunteers, many of whom were chemists and other lab scientists at Lilly, familiar with handling chemicals. Glyphosate, the herbicide of choice, does not require the applicator to be licensed in Indiana. It was selected based on its efficacy in killing Amur bush honeysuckle (www.in.gov/dnr/files/Bush_Honeysuckle. pdf; Hartman and McCarthy 2004), its short half-life in the soil (www.monsanto.com/products/documents/ glyphosate-background-materials/gly_halflife_bkg.pdf), and its approval to be used near waterways (www.dowagro. $\mathrm{com} / \mathrm{vm} /$ products/rodeo.htm). The Indiana State Chemists Office (www.oisc.purdue.edu), with regulatory authority in matters of herbicide application, was consulted and approved the use of volunteers. A further outcome of developing best practices for Amur bush honeysuckle removal was agreement that to effectively remove honeysuckle from a site, three years of repeated effort is needed. A plan for five years of spring foliar spray following the $2012 \mathrm{FC}-\mathrm{HRP}$ by environmental consulting firm Cardno JFNew was agreed upon, along with retreating each fall with more manual removal and spraying as part of subsequent FC-HRP work.

Training volunteers and other citizens to identify Amur bush honeysuckle and understand why it was being targeted for removal. To train the large number of volunteers for the FC-HRP, ROW had the advantage of most of the volunteers working for the same employer (Eli Lilly) who could enforce mandatory training. Training materials, including a video, were developed with the help of the Indiana Chapter of The Nature Conservancy, a local office of an international conservation non-profit with much experience with INS eradication and control. The video can be seen at: youtu.be/ez4V3y0lHBA. It contains background
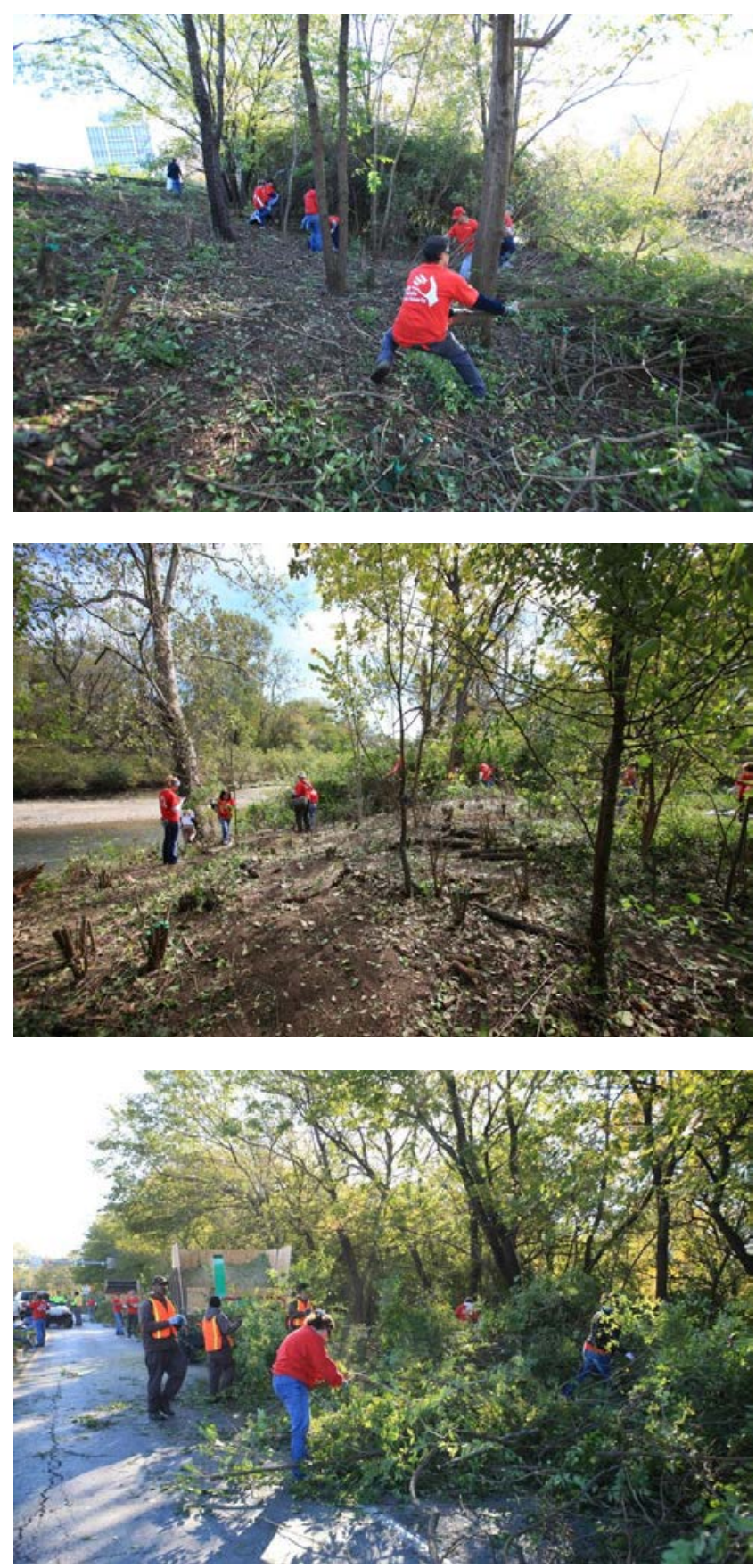

Figure 2. Volunteers clear invasive non-native Amur bush honeysuckle during the 2012 FC-HRP in Indianapolis, IN. Photo credits: Richard Spahr.

information on invasive plants, how to identify Asian bush honeysuckles like Amur bush honeysuckle, and explains the team approach that was employed for the FC-HR. Botanists from Butler University flagged native shrubs and small trees to help volunteers distinguish desirable vegetation from that which was to be removed.

Approval to conduct the work by land owners along Fall Creek. The land immediately adjacent to Fall Creek's northern banks, where the FC-HRP work took place, is owned by the city, having been bought and set aside during the 
Table 2. Logistical planning timeline for 2012 FC-HRP.

\begin{tabular}{|c|c|c|c|c|c|c|}
\hline \multicolumn{7}{|c|}{ Fall Creek Invasive Removal Project Timeline } \\
\hline-8 month & -3 month & -1 month & -1 week & 0 Event & +1 week & +1 year \\
\hline Define & Plan & Train & Prep & Execute & Follow-up & Maintenance \\
\hline $\begin{array}{l}\text { ID focus area } \\
\text { Engage } \\
\text { area stake- } \\
\text { holder and } \\
\text { community }\end{array}$ & $\begin{array}{l}\text { Draft MOU/ } \\
\text { contract for } \\
\text { work and } 5 \text { yr. } \\
\text { maintenance }\end{array}$ & $\begin{array}{l}\text { Conduct flora } \\
\text { inventory to } \\
\text { define scope of } \\
\text { invasion and } \\
\text { mark plant mate- } \\
\text { rial to remain }\end{array}$ & $\begin{array}{l}\text { Assign and } \\
\text { inform volun- } \\
\text { teer, equipment, } \\
\text { materials into } \\
\text { working groups } \\
\text { and areas }\end{array}$ & $\begin{array}{l}\text { Assemble and } \\
\text { direct work- } \\
\text { ing groups to } \\
\text { assigned area }\end{array}$ & $\begin{array}{l}\text { Quantify and } \\
\text { map invasive } \\
\text { removal area, } \\
\text { volunteer } \\
\text { time, etc. for } \\
\text { reporting }\end{array}$ & $\begin{array}{l}\text { In following } \\
\text { spring apply } \\
\text { foliar herbicide } \\
\text { treatment to re- } \\
\text { sprouted areas }\end{array}$ \\
\hline $\begin{array}{l}\text { Define scope } \\
\text { of area and } \\
\text { work }\end{array}$ & $\begin{array}{l}\text { Secure resources } \\
\text { (volunteers, } \\
\text { herbicide, } \\
\text { equipment) }\end{array}$ & $\begin{array}{l}\text { Determine volun- } \\
\text { teer \#s available/ } \\
\text { needed }\end{array}$ & & $\begin{array}{l}\text { Cut, drag, and } \\
\text { chip }{ }^{1} \text { invasive } \\
\text { vegetation } \\
\text { (honeysuckle) }\end{array}$ & & $\begin{array}{l}\text { Conduct flora } \\
\text { inventory to } \\
\text { determine } \\
\text { extent of inva- } \\
\text { sive and native } \\
\text { cover to deter- } \\
\text { mine further }\end{array}$ \\
\hline $\begin{array}{l}\text { Seek per- } \\
\text { mission of } \\
\text { property } \\
\text { owner (if city } \\
\text { owned, seek } \\
\text { approval from } \\
\text { all appropriate } \\
\text { agencies) }\end{array}$ & $\begin{array}{l}\text { Establish date } \\
\text { and time of } \\
\text { project }\end{array}$ & $\begin{array}{l}\text { Volunteer team } \\
\text { captain training }\end{array}$ & & $\begin{array}{l}\text { Certified/trained } \\
\text { herbicide } \\
\text { applicators spray } \\
\text { honeysuckle } \\
\text { stumps }\end{array}$ & & $\begin{array}{l}\text { management } \\
\text { method }^{2}\end{array}$ \\
\hline & & $\begin{array}{l}\text { Obtain permits if } \\
\text { on public land }\end{array}$ & & $\begin{array}{l}\text { Remove trash } \\
\text { and spread } \\
\text { native grami- } \\
\text { noid seed mix }\end{array}$ & & $\begin{array}{l}\text { Continue } \\
\text { maintenance for } \\
5 y e a r s\end{array}$ \\
\hline
\end{tabular}

${ }^{1}$ Hired professional chipping crew

${ }^{2}$ If invasive persist: continue removal and/or foliar spray. If in check but low native cover do supplemental native planting

original Kessler Plan days. A Memorandum of Understanding was drafted to secure agreement from the city, assuring that all affected agencies were consulted and informed.

\section{Results}

On October 11, 2012, a three mile stretch of Fall Creek Parkway was closed to traffic for 4 hours and over 2,000 employees from Eli Lilly and Company and other volunteers removed Amur bush honeysuckle by cutting and lopping (Figure 2), supporting local citizens' desire to see Fall Creek. Logistical planning for the day began at least 8 months before the event (Table 2). Herbicide was applied to cut stumps. Staff from the environmental consulting firm Cardno JF New was on hand to ensure herbicide was used properly and met all state rules for use. Cuttings were dragged to the curb for chipping and taken to a location near the site for final disposal. Volunteers spread seed of native riparian grass and forb species. The Red Cross provided first aid assistance; law enforcement was present in case any fire arms or drug paraphernalia were discovered.

\section{Outputs}

Over 2,000 volunteers removed over $760 \mathrm{~m}^{3}$ of Amur bush honeysuckle from 30 acres of land along Fall Creek during the 2012 FC-HRP (Table 3, Figure 3). Twelve partner organizations included private donors, corporate, city of Indianapolis, non-profits and universities contributed over 1.1 million dollars in cash and services to support the day (See list in Supplementary Table S1).

\section{Outcomes}

In evaluating outcomes in the frame-work of Civic Ecology, outcomes are viewed by impact on communities, not just environmental stewardship (Krasny and Tidball 2012). Table 4 highlights 10 principles of civic ecology and summarizes how they were put into action or fostered during the FC-HRP. Many of these actions correlate with desired ROW initiative outcomes summarized in Table 1. As a result of the 2012 FC-HRP, views of Fall Creek and its historic view sheds from the Kessler Plan were recreated by volunteer action (Outcomes $\# 2$ and 3, Table 4). 
Table 3. Output metrics of 2012 Fall Creek Honeysuckle Removal Project.

\begin{tabular}{lc}
\hline Metric & Total \\
\hline Partners & 12 \\
Estimated cash investment & $\$ 675,000$ \\
Estimated donated services & $\$ 465,700$ \\
Total investment & $\$ 1,140,700$ \\
Total volunteers & 2,148 \\
Total hours & 8,592 \\
Volunteer value* & $\$ 164,700$ \\
Amur bush honeysuckle removed & $30 \mathrm{acres}^{*}$ \\
Chipped material removed & $760 \mathrm{~m}^{3}$ \\
\hline
\end{tabular}

*Based on \$19.17 per volunteer hour (www.independentsector.org/ volunteer_time).

These results were immediate and were directly linked with desired outcomes of the ROW initiative to increase awareness of the importance of waterways in the city through increased visibility of creeks (Table 1).

Other outcomes of the FC-HRP will take longer to develop and evaluate. The degree to which these actions produce ecosystem services (Outcome \#5, Table 4) is being monitored through annual surveys, conducted by ROW staff assisted by neighborhood volunteers, state agencies, and local academic researchers and students, of plants and animals using the creek and creek banks as habitat. It will take several years of surveys to document changes in biodiversity. This aligns with ROW's desired Ecology Element outcome of increased density of habitat that improves ecological form and function (Table 1). Water quality assessment in the creek is also ongoing by state and city agencies. Likewise, it will take several years to assess citizen's use of Fall Creek as a recreational area, whether capital investment increases in the area and whether the human population grows in this urban core (Overall Outcome, Table 1).

Amur bush honeysuckle removal along Fall Creek served ecological and environmental goals of removing an invasive species, but it also helped foster in citizens a sense of place and connection with Indianapolis' historical Kessler Plan, reflecting local history and culture (Outcome \#3, Table 4). Volunteers learned about INS through hands-on experience (Outcome \#7, Table 4), which is an outcome in, and of, itself (Krasny and Tidball 2010). In addition, the FC-HRP may have fostered psychological and physical well-being (ROW Well Being Element metric, Table 1; Outcome \#6, Table 4) by engaging people in working with nature (Krasny and Tidball, 2012), promoting biophilia (Kellert and Wilson 1993), while countering nature deficit disorder (Louv 2006).

Volunteers who worked on the FC-HRP also had the opportunity to see how their local efforts connect with larger-scale ecological issues. The Indiana Field Office of The Nature Conservancy, in conjunction with the Natural Resources Conservation Service, recently released a report documenting that restored floodplain forests in Indiana
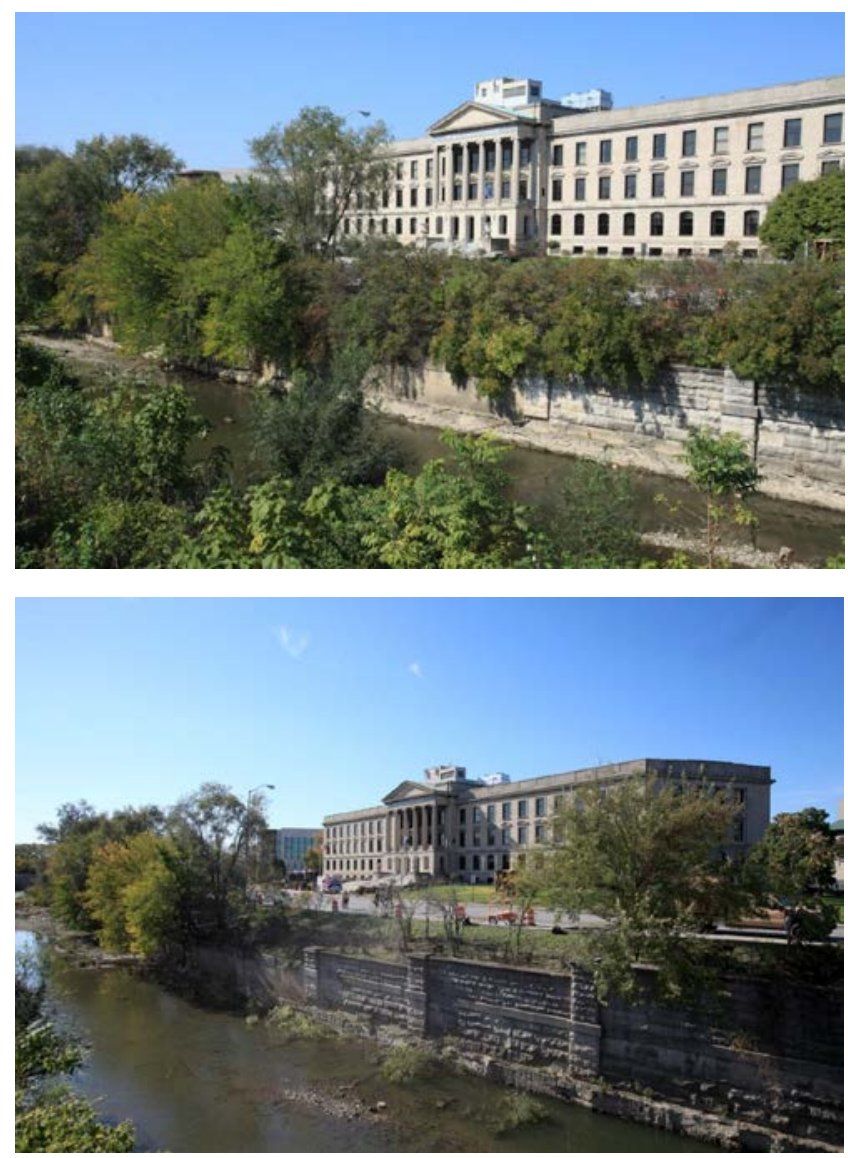

Figure 3. Banks of Fall Creek in Indianapolis, IN before and after volunteers removed Amur bush honeysuckle. Photo credits: Richard Spahr.

are reducing the amount of excess nutrients that leave rural and urban areas of the state, ultimately ending up in the Gulf of Mexico, potentially reducing the infamous "dead zone" in the Gulf (www.nature.org/ourinitiatives/ regions/northamerica/unitedstates/indiana/newsroom/ wabash-river-helps-gulf.xml). The report is being shared with volunteers.

The FC-HRP had a role in empowering the Mid-North neighborhood of Indianapolis to take action to address urban blight; it helped foster a restoration culture (Overall ROW goal, Table 1; Outcome \#9, Table 4). Other neighborhood groups and associations in the area are now seeking to duplicate the success of Amur bush honeysuckle removal along Fall Creek. They see that many objectives can potentially be achieved through removal (ecological, social, and economic) and that removal can lead to multi-functional restoration. Monitoring of these civic ecology practices is enabling on-going adaption based on information about outcomes.

Amur bush honeysuckles and other shrubs escaped from the ornamental horticultural trade are the largest physiognomic group among invasive non-native plants appearing in the flora growing outside of cultivation in Indianapolis over the last 70 years (Dolan et al. 2011). 
Table 4. Principles of Civic Ecology Practice (CEP; Tidball and Krasny 2015) in action and/or fostered during the Fall Creek Honeysuckle Removal Project (FC-HRP) in Indianapolis, Indiana.

Tidball and Kransny (2015)

CEP emerge in broken places

Because of their love for life and love for the places they have lost, civic ecology stewards defy, reclaim, and re-create those broken places

In re-creating place, CEP re-create community

Civic ecology stewards draw on social/ecological memories

CEP produce ecosystem services

CEP foster well-being

CEP provide opportunities for learning

CEP start out as local innovations and expand to encompass multiple partners

CEP are embedded in cycles of chaos and renewal, which in turn are nested into social-ecological systems

Policy makers have a role to play in growing CEP

\section{In Action or Fostered FC-HRP}

Fall Creek Amur bush honeysuckle over the last 50 years gradually blocked view of Fall Creek so completely that most people did not know the creek was there; disconnection from sense of place; perceived as dangerous area

Mid-North neighborhood and ROW through FC-HRP reclaim views of Fall Creek and reestablish historical Kessler Plan view sheds

Fall Creek again becomes an asset to neighborhoods, drawing residents to volunteer to commit to monitor and maintain open vistas

Some residents knew of historical Kessler Plan and recalled formerly open landscape

Removing Amur bush honeysuckle increases biodiversity of native plants and animals (being monitored on on-going basis by Butler University faculty and students); reduces erosion and improves water quality (being monitored by ROW)

Citizens reap benefits of "seeing green"; new recreational trail fosters physical well-being

FC-HRP volunteers and neighborhood groups learned to recognize INS and appreciate their ecological impacts; recognize that not all green vegetation in the city is an asset

Currently 150 partners in ROW including public and private sector, academic institutions and NGOs

Years of cycles of erosion of natural capital and deletion of social capital were broken and the cycle reversed to promote ecosystem services and build social capital

The city of Indianapolis is expanding efforts to reclaim other portions of the Kessler Plan

\section{Conclusions}

underappreciated. The relatively tall stature, long leaf-hold, and dense monoculture stands of Amur bush honeysuckles and other shrubs, including European buckthorn (Rhamnus cathartica), in the Midwestern United States predispose these plants to cause more than ecological impacts in cities.

Finally, an additional feature of the FC-HRP was the central role of the private sector, specifically Eli Lilly, as a governance institution and collaborator in the adaptive comanagement framework of ROW. By enabling ROW, and then involving many partner organizations, Lilly was key in a polycentric governance structure (as defined by Ostrom and colleagues, reviewed in Nagendra and Ostrom 2012) focused on a commonly managed natural resource, Fall Creek. The term "governance" is not to be confused with "government." Polycentric governance in a natural resource context refers to collective action to manage common pool resources that is not driven by a top-down hierarchy, that is, by a single or small numbers of entities or agencies, but by multiple stakeholders who are independent agents at the local level and who are directly affected by the quality and quantity of the target resource (Huitema et al. 2009). We could find no other examples of corporations playing such a central role in civic ecology practice.
1. The Fall Creek Honeysuckle Removal Project initiated in Indianapolis in 2012 is a novel application of civic ecology practice (CEP). The Project's motivation for action (long-developing environmental, social, and economic impacts of an invasive plant species) and the integral role of a major corporation are elements not commonly associated with CEP.

2. The CEP detailed here can serve as a model for action in other cities addressing invasive non-native species. Not all urban areas have the resources or community will to deploy 2,000 volunteers on a single day, but aspects of the planning steps and logistics presented are excellent candidates for duplication.

3. The implications for practice in other cities include: a) Reach out in your community for a broad base and take a polycentric governance approach; b) Look to combine corporate day of service philanthropy with neighborhood association and community plan goals; c) Do not be afraid to think big just because largescale projects have not been done in your area. Work together to achieve in the face of seemingly overwhelming amounts of work. Scale up from smaller 
projects and apply what you learn; and d) Recognize the impacts of invasive non-native plants on cultural, as well as ecological, resources to broaden participation and community connection.

\section{Acknowledgements}

The authors thank all the partner organizations listed in Supplementary Table S1 for financial and logistical support. Kelly Harris was an AmeriCorp VISTA volunteer (www.nationalservice.gov/ programs/americorps/americorps-vista) placed at the Center for Urban Ecology at Butler University, through Indiana University's School for Public and Environmental Affairs, from July 2012 to August 2014.

\section{References}

Collier, M.H., J.L. Vankat and M.R. Hughes. 2002. Diminished plant richness and abundance below Lonicera maackii, an invasive shrub. American Midland Naturalist 147:60-71.

Diebold, P.C. 1994. Kessler's boulevard and park system. Pages 868869 in D.J. Bodenhamer and R.D. Barrows (eds), The Encyclopedia of Indianapolis. Bloomington IN: Indiana University Press.

Dolan, R.W., M.E. Moore and J.D. Stephens. 2011. Documenting effects of urbanization on flora using herbarium records. Journal of Ecology 99:1055-1063.

Gould, A.M.A. and D.L. Gorchov. 2000. Effects of the exotic invasive shrub Lonicera maackii on the survival and fecundity of three species of native annuals. American Midland Naturalist 144:36-50.

Hartman, K.M. and B.C. McCarthy. 2004. Restoration of a forest understory after the removal of an invasive shrub, Amur bush honeysuckle (Lonicera maackii). Restoration Ecology 12: 154-165.

Hartman, K.M. and B.C. McCarthy. 2007. A dendro-ecological study of forest overstory productivity following invasion of the nonindigenous shrub Lonicera maackii. Applied Vegetation Science $1: 3-14$.

Huitema, D., E. Mostert, W. Egas, S. Moellenkamp, C. Pahl-Wostl and R. Yalcin. 2009. Adaptive water governance: Assessing the institutional prescriptions of adaptive (co-) management from a governance perspective and defining a research agenda. Ecology and Society 14:26. URL: www.ecologyandsociety.org/vol14/ iss1/art26/.

Ingold, J.L. and M.J. Craycraft. 1983. Avian frugivory on honeysuckle (Lonicera) in southwestern Ohio in fall. Ohio Journal of Science 83:256-258.

Jordan, R., W.R. Brooks, A. Sorensen and J. Ehrenfeld. 2014. Understanding plant invasions: An example of working with citizen scientists to collect environmental data. AIMS Environmental Science 1:38-44.

Kania J. and M. Kramer. 2011 Collective Impact. Stanford Social Innovation Review 74:36-41.

Kellert, S.R. and E.O. Wilson (eds) 1993. The Biophilia Hypothesis. Washington, D.C.: Island Press.

Krasny, M.E., A. Russ, K.G. Tidball and T. Elmqvist. 2014. Civic ecology practices: Participatory approaches to generating and measuring ecosystem services in cities. Ecosystem Services 7: $177-186$

Krasny, M.E. and K.G. Tidball. 2010. Civic ecology: Linking social and ecological approaches in extension. Journal of Extension 48:1-5.

Krasny, M.E. and K.G. Tidball. 2012. Civic ecology: A pathway for Earth stewardship in cities. Frontiers in Ecology and the Environment 10: 267-273.

Krasny, M.E. and K.G. Tidball. 2015. Civic Ecology: Adaptation and Transformation from the Ground up. Cambridge, MA: MIT Press.

Louv, R. 2006. Last Child in the Woods: Saving our Children from Nature-Deficit Disorder. New York, NY: Algonquin Books.

Luken, J.O. and J.W. Thieret. 1996. Amur bush honeysuckle, its fall from grace. BioScience 46:18-24.

Maloney, M. and K.J. Remenschneider. 1983. Indianapolis Landscape Architecture. Washington, D.C.: Landscape Architecture Foundation.

Nagendra, H. and E. Ostrom. 2012. Polycentric governance of multifunctional forested landscapes. International Journal of the Commons 6:104-133.

Pimentel, D., R. Zuniga and D. Morrison. 2005. Update on the environmental and economic costs associated with alien-invasive species in the United States. Ecological Economics 52:273-288.

Pyšek, P. (1998) Alien and native species in Central European urban floras: A quantitative comparison. Journal of Biogeography 25: 155-163.

Schmidt, K.A. and C.J. Whelan. 1999. Effects of exotic Lonicera and Rhamnus on songbird nest predation. Conservation Biology 13:1502-1506.

Silva, P. and M.E. Krasny. 2014. Parsing participation: Models of engagement got outcomes monitoring in urban stewardship. Local Environments. doi 10.1080/13549839.2014.929094.

Silverton, J. 2009. A new dawn for Citizen Science. Trends in Ecology and Evolution. 24:467-471.

Tidball, K.G. and M.E. Krasny. 2007. From risk to resilience: What role for community greening and civic ecology in cities? Pages 149-164 in A.E.J. Wals (ed), Social Learning Towards a More Sustainable World. Wagengingen, Netherlands: Wagengingen Academic Press.

Tidball, K.G. and M.E. Krasny. 2014. Greening in the Red Zone. New York, NY: Springer.

van Ham, C., P. Genovesi and R. Scalera. 2013. Invasive Alien Species: The Urban Dimension, Case Studies on Strengthening Local Action in Europe. Brussels, Belgium: IUCN European Union Representative.

Rebecca W. Dolan (corresponding author), Butler University Friesner Herbarium, 4600 Sunset Ave., Indianapolis, IN, 46208,rdolan@butler.edu.

Kelly Harris, Current Consulting LLC and Butler University Center for Urban Ecology, 4600 Sunset Ave., Indianapolis, IN, 46208 .

Mark Adler, Keep Indianapolis Beautiful, Inc., 1029 Fletcher Ave \#100, Indianapolis, IN, 46203. 